National Assessment of Oil and Gas Project

\title{
Map of Assessed Shale Gas in the United States, 2012
}

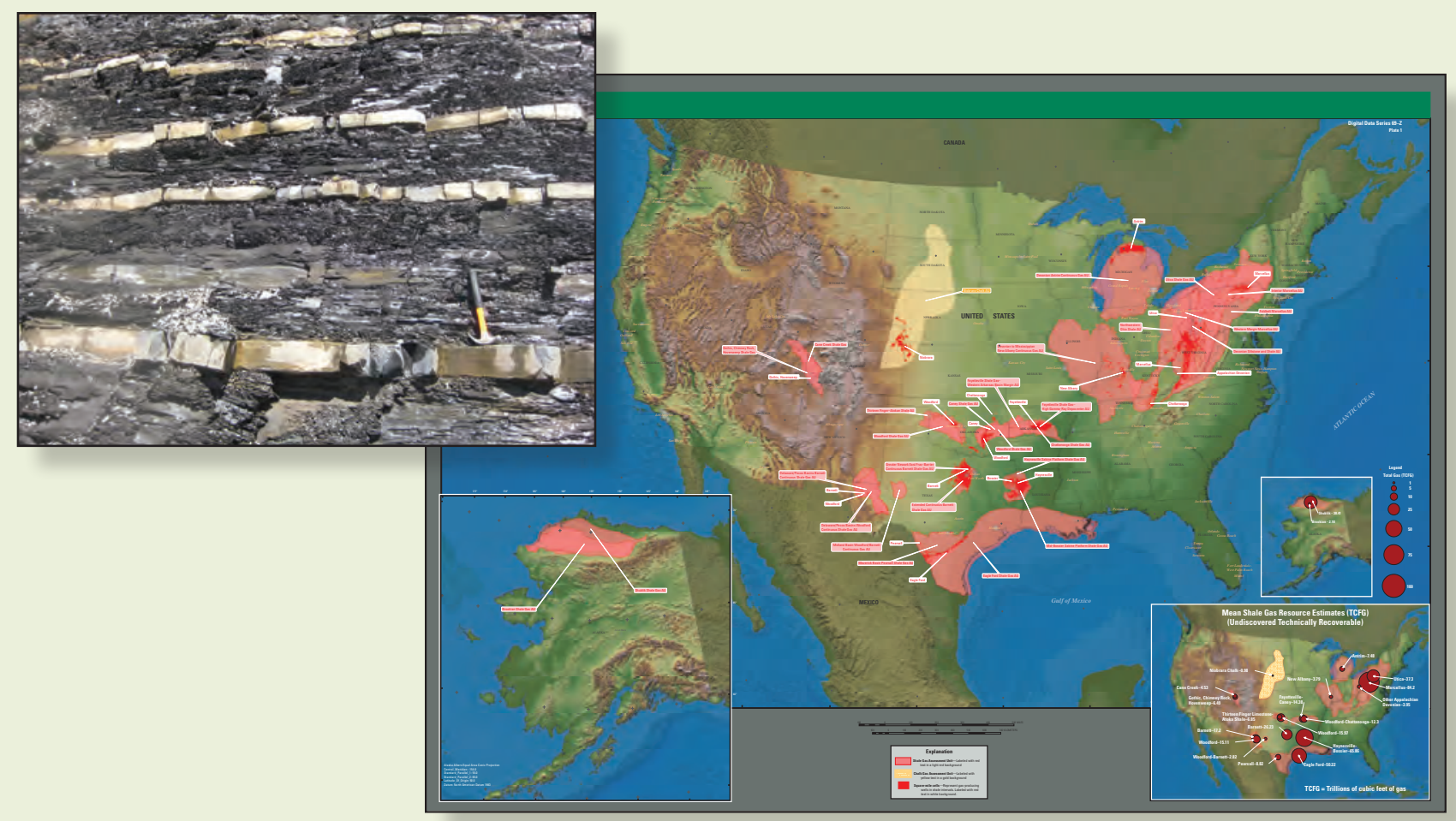

Digital Data Series DDS-69-Z 


\section{Map of Assessed Shale Gas in the United States, 2012}

By U.S. Geological Survey National Assessment of Oil and Gas Resources Team, and Laura R.H. Biewick, compiler

U.S. Geological Survey National Assessment of Oil and Gas Project

Digital Data Series 69-Z 


\title{
U.S. Department of the Interior \\ KEN SALAZAR, Secretary
}

\section{U.S. Geological Survey \\ Suzette M. Kimball, Acting Director}

\author{
U.S. Geological Survey, Reston, Virginia: 2013
}

For more information on the USGS - the Federal source for science about the Earth, its natural and living resources, natural hazards, and the environment, visit http://Www.usgs.gov or call 1-888-ASK-USGS.

For an overview of USGS information products, including maps, imagery, and publications, visit $h t t p: / / w w w . u s g s . g o v / p u b p r o d$

To order this and other USGS information products, visit http://store.usgs.gov

Any use of trade, firm, or product names is for descriptive purposes only and does not imply endorsement by the U.S. Government.

Although this information product, for the most part, is in the public domain, it also may contain copyrighted materials as noted in the text. Permission to reproduce copyrighted items must be secured from the copyright owner.

Suggested citation:

U.S. Geological Survey National Assessment of Oil and Gas Resources Team, and Biewick, L.R.H., compiler, 2013, Map of assessed shale gas in the United States, 2012: U.S. Geological Survey Digital Data Series 69-Z, 16 p., 1 pl., GIS data package, http://pubs.usgs.gov/dds/dds-069/dds-069-z/. 


\section{Contents}

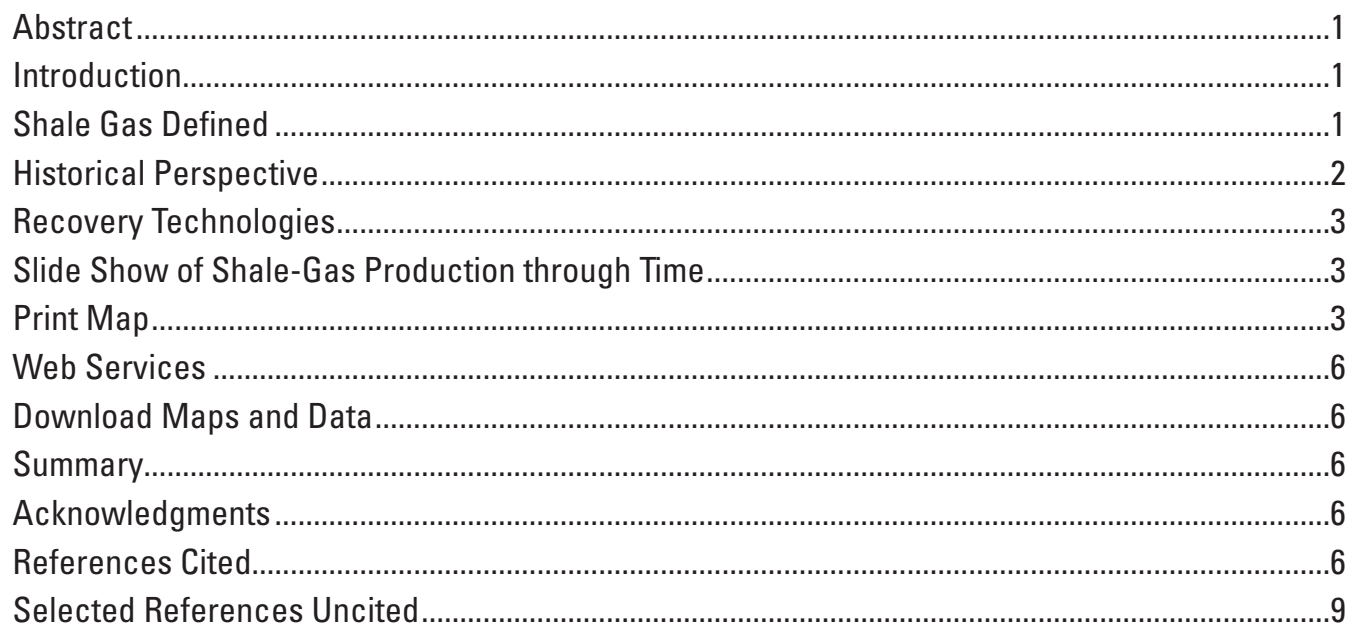

\section{Plate}

1. Map of assessed shale gas in the United States, 2012 .............................................. link

\section{Figures}

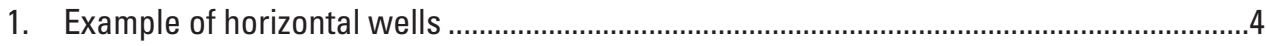

2. Map graphic that links to the hardcopy map .................................................................

\section{Table}

1. Publications access table-Hyperlinks to USGS shale-gas assessment publications and web pages

\section{Conversion Factors}

Inch/Pound to SI

\begin{tabular}{lcc}
\hline Multiply & By & To obtain \\
\hline & Volume & \\
\hline Cubic foot $\left(\mathrm{ft}^{3}\right)$ & 0.02832 & cubic meter $\left(\mathrm{m}^{3}\right)$ \\
\hline SI to Inch/Pound & & \\
\hline Multiply & By & To obtain \\
\hline & Length & \\
\hline millimeter $(\mathrm{mm})$ & 0.03937 & inch (in.) \\
\hline
\end{tabular}





\title{
Map of Assessed Shale Gas in the United States, 2012
}

\author{
By U.S. Geological Survey National Assessment of Oil and Gas Resources Team, \\ and Laura R.H. Biewick, compiler
}

\section{Abstract}

The U.S. Geological Survey has compiled a map of shal e-gas assessments in the U nited States that were completed by 2012 as part of the U.S. Geological Survey National Assessment of Oil and Gas Project. Using a geology-based assessment methodology, the U.S. Geological Survey quantitatively estimated potential volumes of undiscovered gas within shale-gas assessment units. These shal e-gas assessment units are mapped, and square-mile cells are shown to represent proprietary shale-gas wells. The square-mile cells include gasproducing wells from shale intervals.

In some cases, shale-gas formations contain gas in deeper parts of a basin and oil at shallower depths (for example, the Woodford Shale and the E agle Ford Shale). B ecause a discussion of shale oil is beyond the scope of this report, only shalegas assessment units and cells are shown.

The map can be printed as a hardcopy map or downloaded for interactive analysis in a Geographic Information System data package using the ArcGIS map document (file extension MXD) and published map file (file extension PMF). A Iso available is a publications access table with hyperlinks to current U.S. Geological Survey shale-gas assessment publications and web pages. A ssessment results and geologic reports are available as completed at the U.S. Geological Survey Energy Resources Program Web Site, http://energy.usgs.gov/ O ilG as/AssessmentsD ata/N ationalO ilG asAssessment.aspx.

A historical perspective of shale-gas activity in the $U$ nited States is documented below and presented in a video clip included as a PowerPoint slideshow.

\section{Introduction}

Shale-gas activity in the U nited States began with the first well dug specifically to produce natural gas in 1821 in Devonian shal es near the town of Fredonia, N ew Y ork. A primer on U.S. shale-gas production, released in 2009, by the U.S. Department of Energy (DOE), noted that unconventional gas production now accounts for 46 percent of total U.S. gas production (U.S. Department of E nergy, N ational Energy Technology Laboratory, 2009). In a 5-year time span (2004 to 2009), U.S. shale-gas production grew from 2 billion cubic feet per day (BCFD) to more than 8 BCFD (Stevens and
K uuskraa, 2009). The heightened interest in shale gas began with the B arnett Shale in N orth Texas, followed by development of the Fayetteville Shale in A rkansas, the Woodford Shale in Oklahoma, the Haynesville/B ossier Formations in L ouisiana and Texas, the M arcellus Shale in the A ppalachian B asin, and the Eagle Ford in Texas. Together with the A ntrim Shale in M ichigan and A ppalachian Basin Devonian shales, these are the most active producing gas shales to date. In addition to these, others are being explored or evaluated, and some are emerging from exploration to exploitation. Each shale-gas basin is different with respect to the geologic setting and character of its gas-bearing shales, so each basin has a unique set of exploration criteria and operational challenges (U.S. Department of Energy, N ational Energy Technology L aboratory, 2009). A s for conventional-type plays, an in-depth understanding of the geology, petrophysics, and geomechanics of a particular shale formation is essential to achieve success in exploration and development of shale gas (D urham, 2009a); however, conventional methods of production are commonly unsuitable for these continuous-type plays.

\section{Shale Gas Defined}

Shale is a fine-grained sedimentary rock, characterized by its grain size $(<1 / 256 \mathrm{~mm})$ and fissility. It contains clay minerals and fine grains of quartz and feldspars, plus organic material, but the classification of "shale" still rests on particle size rather than mineralogy (Forgotson, 2006).

Cardott (2004) defined gas shales as containing a minimum of $0.5 \mathrm{wt}$ percent total organic carbon (TOC). Gas shales may be thermally marginally mature (vitrinite reflectance $\left(R_{0}\right)$ $0.4-0.6$ percent $)$ to mature $\left(0.6-2.0\right.$ percent $\left.R_{0}\right)$ and contain biogenic to thermogenic methane. Gas is generated and stored in situ in gas shales as both sorbed (on organic matter) and as free gas (in fractures and pores), similar to natural gas in coals.

Gas shales are traditionally viewed as both source rocks and seals for stratigraphic gas accumulations (Denney, 2009). Cole and others (1987) reported that gas shales constitute source, as well as reservoir rock and seal, and that hydrocarbon migration distances within the shale are relatively short. Conventional reservoirs situated stratigraphically above or below the shale also may be concurrently charged with hydrocarbons generated by the same shale source rocks. 
A Rocky Mountain region shaly source rock, the Cretaceous N iobrara, is rich in organic carbon and contains significant carbonate material. The lithology of the formation was controlled by many factors during deposition in a major marine transgression of the Western Interior Seaway, ranging from siliciclastic-rich intervals in the western part of the seaway (western Colorado) to chalk and marlstone in eastern Colorado (Longman and others, 1998). Considering the Niobrara as a fine-grained source rock also places chalks and marlstones in the category of shale plays (Hill and others, 2008).

In addition to the variety of lithologies that can be interbedded with shale-gas source rocks, some of the shalegas formations generate gas in deeper parts of the basin but oil at shallower depths, for example, the Woodford Shale and the Eagle Ford Shale. Factors that have spurred the explosive growth of shale-gas plays include development of a greater geologic understanding, advances in drilling and completion techniques, and access to land and infrastructure (Stevens and K uuskraa, 2009).

\section{Historical Perspective}

The earliest references to black organic-rich shale units were by French explorers and missionaries from 1627-1669, who noted occurrences of oil and gas now believed to be sourced by Devonian shales in western New York (Roen, 1993). In 1821, William Hart dug the first well specifically to produce natural gas in the U nited States, in the village of F redonia on the banks of Canadaway Creek in Chautauqua County, N ew York. It was excavated to a depth of 27 feet with shovels by hand, and its gas pipeline was hollowed-out logs sealed with tar and rags (Hill and others, 2008). The gas was used to illuminate the town of Fredonia (Roen, 1993). Gas was discovered in Devonian and M ississippian shales in the western Kentucky part of the Illinois Basin in 1863 (Curtis, 2002). Drilling commenced in Pennsylvania in the 1850s and was extended into Ohio a decade later (Janssens and deWitt, 1976). By the 1920s, drilling for shale gas had progressed into West Virginia, Kentucky, and Indiana (Curtis, 2002), and by 1926, the Devonian shale-gas fields of eastern Kentucky and West Virginia comprised the largest known natural gas occurrences in the world (Roen, 1993).

A necdotal accounts of gas shows and local consumption are also part of the history of settlement in the Northern Great Plains during the late nineteenth and early twentieth centuries (Shurr, 2008). Cretaceous shales crop out and (or) are in subcrops al ong the eastern margin of the Williston B asin in North and South Dakota. Glacial deposit aquifers above shale subcrops commonly had natural gas in sufficient quantities for domestic use in a single home to commercial use for small municipalities. Much of this gas was recognized as coming from Cretaceous shales (Wilson, 1922; as reported in Shurr, 2008).

Following the energy crisis of 1973, the onset of energy shortages and the subsequent increase in natural gas prices spurred the U.S. Department of Energy to fund a multistate cooperative program called the Eastern Gas Shales Project (EGSP) that spanned the Appalachian, Illinois, and Michigan Basins (Harper, 2008). The EGSP functioned to integrate planning and research of some 40 organizations from 15 states to exchange and evaluate information and technology to learn about the gas-producing potential of Devonian shale. The deeper shales were considered to be much less attractive targets and would remain so until gas prices increased and technology advanced enough to make drilling and completion competitive with more conventional targets (Harper, 2008).

The Federal Tax Section 29 nonconventional fuels production tax credit in the 1980s helped develop and boost the economics of marginally productive organic-rich gas shales (Stevens and Kuuskraa, 2009). This early initiative spurred development of new technologies. The credit applied to gas produced from formations classified as "tight" from wells drilled after December 31, 1979, but before January 1, 1993, and the gas being sold before January 1, 2003. Prior to 1994, the Ohio Shale (Appalachian Basin) produced the majority of U.S. shale gas, until the drilling boom in the $M$ ichigan $B$ asin elevated the A ntrim Shale to the top position (Curtis, 2002). The A ntrim Shale was the most active U.S. natural gas play in the early to mid-1990s (Hill and others, 2008). Tax Section 29 expired in 1993; however, the state of Texas continued the tight reservoir severance tax relief, and the Barnett Shale qualifies for this tax relief, thus maintaining interest in the play (M . A . Denham, 2004, personal commun.; as reported in M artineau, 2007). Commercial gas production was established from the M ississippian Barnett Shale in the Fort Worth Basin in the early 1980s, but did not expand until the late 1990s; it is now one of the most active natural gas plays in the U nited States (Hill and others, 2008).

Exploration, drilling, and production of shale-gas plays such as the B arnett, Fayetteville, and Haynesville have changed the unconventional gas industry. Two technologies that enhanced shale-gas development are horizontal drilling and hydraulic fracturing (Denney, 2009), which are discussed in the following section. In addition, more is understood about the B arnett Shale after the drilling of more than 3,000 vertical wells and an increasing number of horizontal wells (Martineau, 2007). Development of the Fayetteville began in the early 2000 s as gas companies that had success developing the B arnett Shale of the Fort Worth Basin identified parallels between it and the $M$ ississippian-aged Fayetteville Shale in terms of age and geologic character (U.S. D epartment of Energy, National Energy Technology Laboratory, 2009).

The modern era of $M$ arcellus Shale production in the Appalachian Basin began in 2004 when Range Resources completed the Renz Unit no.1 well in Washington County, Pennsylvania, using large B arnett style slick-water fracturing (Wrightstone, 2009). Since 2005, the expansion of Marcellus Shale development has continued in Pennsylvania and the A ppalachian B asin (A rthur and others, 2008). In 2007, after several years of drilling and testing, the Haynesville shale made headlines as a potentially significant gas resource (U.S. D epartment of Energy, National Energy Technology L aboratory, 2009). However, it was not until early 2008 that 
operators realized that the Haynesville/Bossier Formation might be as commercially attractive as the other shal e-gas plays (Railroad Commission of Texas, 2010b).

Hill and others (2008) pointed out that, whereas oil production spread rapidly from east to west across the U nited States, shale-gas production was much slower to develop. Focused efforts have now begun in the Rocky Mountain region; however, recent drilling experience in areas such as the Cretaceous shales of the Rocky Mountain region shows that the Barnett play concept does not translate into success in other geologic situations. The recipe for success is more complicated, in part because of a lack of understanding of the geologic processes involved (Hill and others, 2008).

\section{Recovery Technologies}

The low natural permeability of shale has been the limiting factor in the exploitation of shale gas (Denney, 2009), but the advent of horizontal drilling and hydraulic fracturing has facilitated the expansion of modern shale-gas development.

Although the first horizontal well was drilled in Texas in 1929, it was not until the 1980s that the technology was improved enough to become a standard industry practice. The technology involves drilling a vertical hole to several hundred feet above the target reservoir, then directing the drill bit through an arc until it is drilling essentially horizontally (Harper, 2008), as shown in figure 1. The advantages of horizontal wells (for example, see Harper, 2008) include (1) increases in the amount of reservoir penetrated from possibly a few tens of feet to over 5,000 feet, (2) increases in the number of vertical or subvertical fractures intersected, and (3) it can be used to develop hydrocarbon resources beneath sensitive areas such as wetlands and cities where a drilling rig cannot be set up. A systematic approach to well construction, data collection, and pre-fracture diagnostics is an essential component in the quest for the most effective hydraulic-fracture stimulation and the best chance to achieve commercial gas production (Bybee, 2009). M ineralogy low in ductile clays and high in brittle quartz, feldspar, and carbonate components helps promote fracturing effectiveness (Stevens and Kuuskraa, 2009).

The design process for a hydraulic-fracture treatment starts with pre-stimulation reservoir evaluation, which involves collecting field data and gaining an understanding of the character of the reservoir and of the dynamics of existing stress relations. Collected data include porosity, permeability, and lithology of the producing formation; fluid-saturation data; natural-fracture character; and current stress regimes that identify the maximum and least principal horizontal stresses (Denney, 2009). The operator creates effective permeability by fracturing the shale in a manner that connects with natural fractures. $N$ atural fractures help propagate hydraulic fractures as planes of weakness. L arge-scale natural fractures and faults are detrimental - they can limit effective horizontal lateral lengths, absorb hydraulic fracture energy, and serve as conduits for water (K uuskraa and Stevens, 2009). Fractures must be away from faults, and need barriers to stay in-zone.
It was not until development of the B arnett Shale play in the 1990s that a technique suitable for fracturing shales was developed. This technique, called a "slick-water frac" consists of sand and large volumes of freshwater that have been treated with a friction reducer such as a gel. Slick-water fracs maximize the length of the fractures horizontally while minimizing the vertical fracture height, resulting in greater gas mobility and more efficient recovery of a larger volume of the gas (Harper, 2008).

\section{Slide Show of Shale-Gas Production through Time}

For a historical perspective of shale-gas production activity in the U nited States, this report includes a slide show of shalegas production in 10-year increments from the early 1900s to 2012. Digital data were used from the more than 3 million wells in IHS Energy, Inc.'s PI/D wights PLUS Well Data (IHS Energy, 2012). In some areas, the IHS data tend not to be complete, particularly in areas where current commercial activity is high. IHS data were supplemented with State and other wells databases for the Fayetteville (A rkansas), H aynesville (L ouisiana), Caney (Oklahoma) and Woodford (O klahoma) shales.

Because of the proprietary nature of many of these databases, exact drill-hole locations cannot be shown. Therefore, the mapped area was divided into a grid of square-mile cells and the well production status was aggregated. The cells were then converted to polygons attributed to indicate the shale-gas formation. No proprietary data are displayed or included in the cell maps. All map figures use imagery from ArcGIS Online, the National O ceanic and A tmospheric A dministration, and the U.S Geological Survey (USGS). The slideshow is available on the CD-ROM and the website (http://pubs.usgs.gov/dds/dds-069/ dds-069-z/). Press the escape key (ESC) to end the slideshow, or navigate the vertical scroll bar to view a particular time frame.

\section{Print Map}

The shale-gas map is available both as a static Portable Document Format (PDF) file, and as an interactive map that is contained on CD-ROM and is accessible at http://pubs.usgs.gov/dds/dds-069/dds-069-z/. Software used to create this digital map product includes: Environmental Systems Research Institute, Inc. (ESRI) ArcGIS 9.3, Python, Adobe Photoshop CS5.1, Illustrator CS5.1, and Acrobat 7.0.

To open the hardcopy map, click on the map graphic shown in figure 2. This action opens the static map in A dobe A crobat Portable D ocument Format (PDF). A dobe A crobat Reader software must be installed to view the PDF map and is available for download at http://get.adobe.com/reader/.

The hardcopy map is designed to be plotted at a sheet size of 36 " wide by 26 " high. A printed map can be ordered from USGS M aps on D emand at http://store.usgs.gov/. 


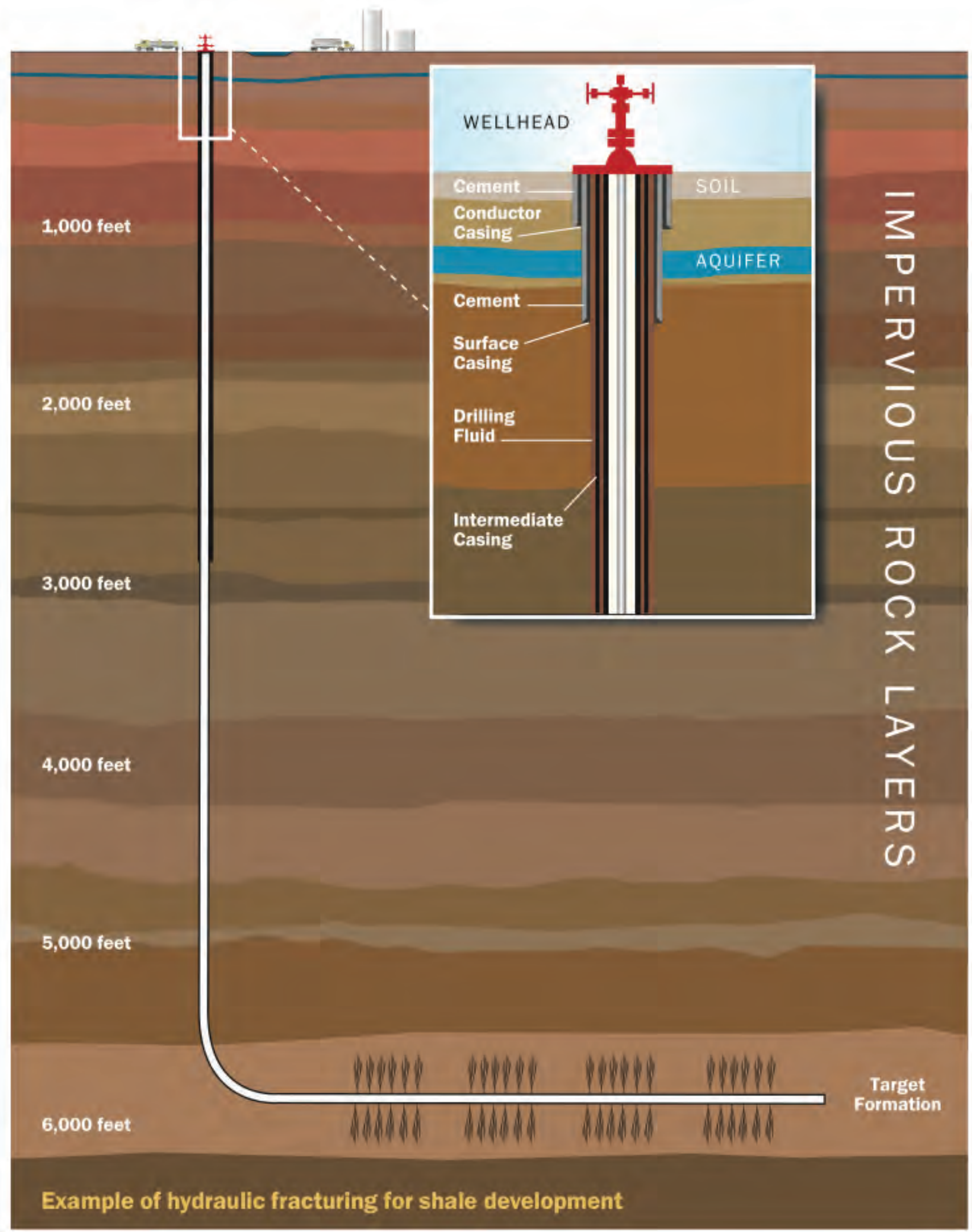

Figure 1. Example of horizontal wells (Reproduced courtesy of EnergyFromShale.org., ${ }^{\oplus}$ the American Petroleum Institute. Used with permission). 


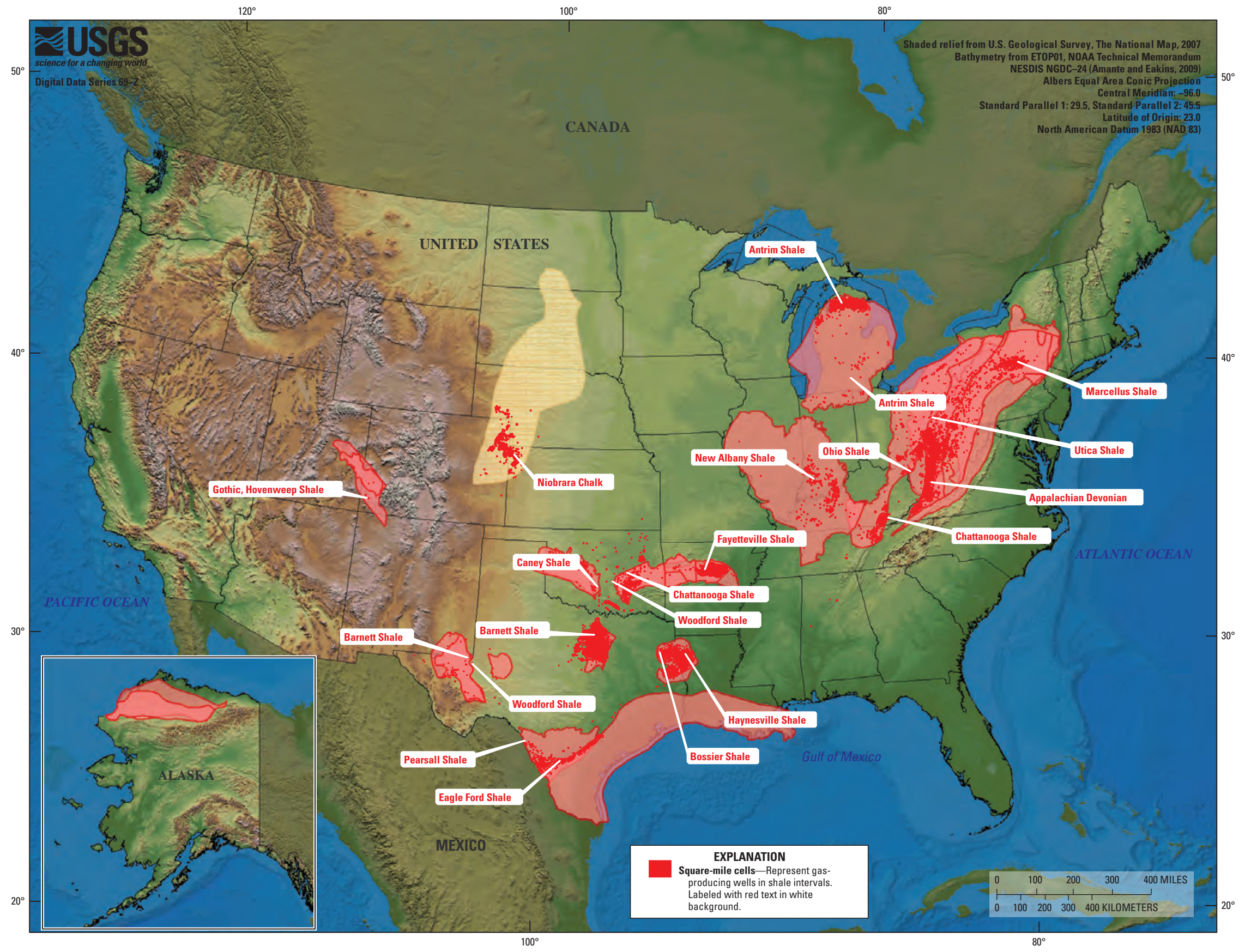




\section{Web Services}

This report includes an interactive map application as a visual analysis tool and to deliver data to the public. To access the shale-gas web service, visit the USGS National Assessment of Oil and Gas Resources website at http://energy.usgs.gov/ O ilGas/AssessmentsData/NationalO ilG asAssessment.aspx.

\section{Download Maps and Data}

The Map of Assessed Shale Gas is available as a Geographic Information System (GIS) map and data package (both MXD and PMF formats) that is contained on CD-ROM or can be downloaded at the USGS website for this report (http://pubs.usgs.gov/dds/dds-069/dds-069-z/). The GIS allows one to visualize, question, analyze, and understand the shalegas data in ways that reveal relations, patterns, and trends more effectively than with the static PDF map. The publishing process uses the ArcMap project (MXD) and creates a special file called a published map file (PMF). ArcGIS Publisher (ESRI, 2008a) is the extension used to create the PM F from the M XD; it packages the required data with the PMF file for easy distribution. PMFs can be viewed, explored, or printed using any ArcGIS (ESRI, 2000) desktop product, including ArcMap and the free ArcReader (ESRI, 2008b) application. Users can download and install the free ArcReader software from ESRI. To access the MXD requires ArcGIS 9.3.1 or later software (ESRI, 2000).

All data are stored in file-based geodatabase (ESRI, 2012) format (ShaleGasAUs2012.gdb, ShaleGasCells2012.gdb and BaseLayers.gdb) and shapefile format using the World Geodetic System (WGS) 1984 projection, which is a standard projection for distributing geospatial data. The polygons represent shale-gas assessment units (AU) that have been defined by the USGS, and square-mile cells are shown to represent proprietary shale-gas wells.

A $\cap \mathrm{AU}$ is a mappable part of a petroleum system in which discovered and undiscovered accumulations constitute a single, relatively homogeneous population that share similar geologic characteristics. M any of the A Us overlap one another; these layers can be mapped together or individually using GIS. An important aspect of this map product is that its use does not require extensive GIS expertise or highly specialized equipment. The Metadata folder contains documentation in XM L, html and text format. For the ArcGIS.com web services (formerly ArcGIS Online; ESRI, 2010), data descriptions, sources, and credits are stored as layer properties. With the ESRI World_Street_Map service, detailed data, such as railroads and airports, appear as the user zooms in at larger scales. Base reference layers included from "The National A tlas of the United States of A merica" (USDOI, 2008) are county boundaries, streams, and water bodies. A layer that represents geology of the conterminous United States (Shruben and others, 1994) is included for reference, and a generalized USGS North A merican color shaded relief raster is included as well.

\section{Summary}

The USGS map of the principal shale-gas assessment units in the U nited States portrays the occurrence of this important resource in many regions of the country. A lthough the complexities of the geologic parameters that bear on the success of a shale-gas play in a given basin or setting may not yet be fully understood, critical knowledge is accumulating as drilling progresses and as advances are being made in engineering and completion technologies. Recent and substantial improvements in both areas have caused shale-gas plays once believed to have limited economic viability to be reevaluated. Estimates of the shale-gas resource, especially the portion that is technically recoverable, are likely to change over time as understanding of the resource characteristics increases with further advances in recovery methods.

\section{Acknowledgments}

This report is a compilation of work by many USGS geologists who defined and assessed shale-gas and chalk-gas assessment units. Thanks are extended to numerous geologists and GIS data specialists who provided critical insights and data download sites. The manuscript was technically reviewed by Christopher J. Schenk, Lawrence O. Anna, and William R. K eefer. I thank them for their thoughtful evaluations and suggested revisions. Thanks also go to the $N$ ational A ssessment of Oil and Gas GIS staff, led by Christopher P. Anderson, A DC M anagement Services, for producing the assessment unit boundaries as GIS layers.

\section{References Cited}

Amante, Christopher, and Eakins, B.W., 2009, ETOP01 1 Arcminute global relief model-Procedures, data sources and analysis: $\mathrm{N}$ ational $\mathrm{O}$ ceanic and $\mathrm{A}$ tmospheric $\mathrm{A}$ dministration (NOAA) Technical Memorandum NESDIS NGDC-24, 19 p. Available at http://www.ngdc.noaa.gov/mgg/global/ relief/ETOP 01/.

A rthur, J.D., B ohm, B rian, and Layne, M., Ph.D., 2008, Hydraulic fracturing considerations for natural gas wells of the $M$ arcellus Shale, in The Ground Water Protection Council 2008 Annual Forum, Cincinnati, Ohio, Sept. 21-24, 2008: Ground Water Protection Council.

Bybee, K aren, 2009, Unconventional resources- Proper evaluation of shale-gas reservoirs leads to more-effective hydraulic-fracture stimulation J ournal of Petroleum Technology. Accessed on July 10, 2012 at http://www.spe.org/ jpt/print/archives/2009/07/.

Cardott, B.J., 2006, Frontier gas - shale plays of Oklahoma, in Mid-Continent Coalbed Methane and Gas Shale Conference Symposium II, Tulsa, Okla., Oct. 23, 2006: Oklahoma Independent Petroleum A ssociation. 
Cardott, B.J., 2007, Gas shale database, July 2007 update: Oklahoma Geologcial Survey, Databases. Accessed on May 12, 2010 at http://www.ogs.ou.edu/level3-databases.php.

Cole, G.A., Drozd , R.J., Sedivy , R.A., and Halpern, H.I., 1987, Organic geochemistry and oil-source correlations, Paleozoic of Ohio: American Association of Petroleum Geologists Bulletin, v. 71, no. 7, p. 788-809.

Coleman, J.L., Swezey, C.S., Ryder, R.T., Charpentier, R.R., Milici, R.C., Hatch, J.R., Cook, T.A., Klett, T.R., Pollastro, R.M., Schenk, C.J., and Schmoker, J.W., 2006, Undiscovered oil and gas resources underlying the U.S. portions of the Great Lakes, 2005: U.S. Geological Survey Fact Sheet 2006-3049, 4p. Available at http://pubs.usgs.gov/ fs/2006/3049/.

Coleman, J.L., Milici, R.C., Cook, T.A., Charpentier, R.R., Kirshbaum, M.A., Klett, T.R., Pollastro, R.M., and Schenk, C.J., 2011, Assessment of undiscovered oil and gas resources of the Devonian M arcellus Shale of the A ppalachian Basin Province, 2011: U.S. Geological Survey Fact Sheet 2011-3092, 2 p. Available at http://pubs.usgs.gov/ fs/2011/3092/.

Curtis, J.B ., 2002, Fractured shale-gas systems: A merican Association of Petroleum Geologists Bulletin, v. 86, no. 11, p. 1921-1938. Accessed on May 12, 2010 at http://search.datapages.com/data/bulletns/2002/11nov/1921/ images/02_1921.pdf.

Denney, Dennis, ed., 2009, H ealth, safety, and environmentEvaluating implications of hydraulic fracturing in shale-gas reservoirs: Journal of Petroleum Technology, v. 61, no.8. Accessed on July 10, 2012 at http://www.spe.org/jpt/print/ archives/2009/08/.

Dubiel, R.F., Warwick, P.D., Swanson, Sharon, Burke, Lauri, Biewick, L.R.H., Charpentier, R.R., Coleman, J.L., Cook, T.A., Dennen, K ris, Doolan, Colin, Enomoto, Catherine, Hackley, P.C., Karlsen, A.W., Klett, T.R., Kinney, S.A., Lewan, M.D., M errill, M att, Pearson, K rystal, Pearson, O.N., Pitman, J.K., Pollastro, R.M., Rowan, E.L., Schenk, C.J., and Valentine, Brett, 2011, Assessment of undiscovered oil and gas resources in J urassic and Cretaceous strata of the Gulf Coast, 2010: U.S. Geological Survey Fact Sheet 2011-3020, 4 p. Available at http://pubs.usgs.gov/ fs/2011/3020/.

Dubiel, R.F., Pitman, J.K., Pearson, O.N., Pearson, Krystal, Kinney, S.A., Lewan, M.D., Burke, Lauri, Biewick, L.R.H., Charpentier, R.R., Cook, T.A., Klett, T.R., Pollastro, R.M., and Schenk, C.J., 2012, Assessment of undiscovered oil and gas resources in conventional and continuous petroleum systems in the Upper Cretaceous Eagle Ford Group, U.S. Gulf Coast region, 2011: U.S. Geological Survey Fact Sheet 2012-3003, 2 p. Available at http://pubs.usgs.gov/ fs/2012/3003/.
Durham, L.S., 2009a, Integrated data aid decisions-Shale calls for the unconventional: A merican A ssociation of Petroleum Geologists Explorer, May 2009 issue. Accessed on July 9, 2012 at http://www.aapg.org/explorer/2009/05may/ shale0509.cfm.

EnergyFromShale.org, 2012, The process of shale extraction: Reproduced courtesy of the American Petroleum Institute. Accessed on June 27, 2012 at http://www.energyfromshale.org/ shale-extraction-process.

Environmental Systems Research Institute, Inc. (ESRI), 2000, ArcGIS: ESRI, Redlands, Calif. Accessed on Jan. 27, 2012 at http://www.esri.com/software/arcgis/index.html.

Environmental Systems Research Institute, Inc. (ESRI), 2008a, ArcPublisher: ESRI, Redlands, Calif. Accessed on Jan. 27, 2012 at http://www.esri.com/software/arcgis/ extensions/publisher/index.html and http://www.esri.com/ software/arcgis/extensions/publisher/publishing.html.

Environmental Systems Research Institute, Inc. (ESRI), 2008b, ArcReader: ESRI, Redlands, Calif. Accessed on Jan. 27, 2012 at http://www.esri.com/software/arcgis/ arcreader/download.html.

Environmental Systems Research Institute, Inc. (ESRI), 2010, ArcGIS online: ESRI, Redlands, Calif. Accessed on Jan. 27, 2012 at http://www.esri.com/software/arcgis/arcgisonline/ index.html.

Environmental Systems Research Institute, Inc. (ESRI), 2012, Geodatabase, ESRI, Redlands, Calif. Accessed on January 27, 2012 at http://www.esri.com/software/arcgis/ geodatabase/index.html.

Forgotson, J.M., 2006, Distribution and properties of shale gas in the A rkoma B asin, in RPSEA-University of Oklahoma Shale Gas Forum, Norman, Okla., Dec. 5th, 2006: University of Oklahoma, College of Earth and Energy School of Geology and Geophysics. Accessed on May 12, 2010 at http://www.rpsea.org/forums/shale_forgotson.pdf.

Harper, J.A., 2008, The Marcellus Shale_-An old "new" gas reservoir in Pennsylvania: Pennsylvania Geology, v. 38, no. 1.

Higley, D.K., Charpentier, R.R., Cook, T.A., Klett, T.R., Pollastro, R.M., and Schmoker, J.W., 2003, 2002 USGS A ssessment of oil and gas resource potential of the Denver B asin Province of Colorado, K ansas, N ebraska, South Dakota, and Wyoming: U.S. Geological Survey Fact Sheet FS-002-03, 3 p. Available at http://pubs.usgs.gov/ fs/fs-002-03/.

Higley, D.K ., compiler, 2007, Petroleum systems and assessment of undiscovered oil and gas in the Denver B asin Province, Colorado, K ansas, Nebraska, South D akota, and WyomingUSGS Province 39: U.S. Geological Survey Digital Data Series DDS-69-P. Available at http://pubs.usgs.gov/dds/ dds-069/dds-069-p/. 
Higley, D.K., Gaswirth, S.B., Abbott, M.M., Charpentier, R.R., Cook, T.A., Ellis, G.S., Gianoutsos, N.J., Hatch, J.R., Klett, T.R., Nelson, Philip, Pawlewicz, M.J., Pearson, O.N., Pollastro, R.M., and Schenk, C.J., 2011, Assessment of undiscovered oil and gas resources of the A nadarko B asin Province of Oklahoma, K ansas, Texas, and Colorado, 2010: U.S. Geological Survey Fact Sheet 2011-3003, 2 p. Available at http://pubs.usgs.gov/fs/2011/3003/.

Higley, D.K., 2011, Undiscovered petroleum resources for the Woodford Shale and Thirteen Finger Limestone-A toka Shale assessment units, Anadarko Basin: U.S. Geological Survey Open-File Report 2011-1242, 3 sheets. Available at http://pubs.usgs.gov/of/2011/1242/.

Hill, D.G., Curtis, J.B., and Lillis, P.G., 2008, Update on North A merica shale-gas exploration and development, in Hill, D.G., Lillis, P.G., and Curtis, J.B., eds., 2008, Gas shale in the Rocky Mountains and beyond, 2008 Guidebook: Rocky Mountain Association of Geologists, Denver, Colo.

Houseknecht, D.W., Coleman, J.L., Milici, R.C., Garrity, C.P., Rouse, W.A., Fulk, B.R., Paxton, S.T., Abbott, M.M., Mars, J.C., Cook, T.A., Schenk, C.J., Charpentier, R.R., Klett, T.R., Pollastro, R.M., and Ellis, G.S., 2010, Assessment of undiscovered natural gas resources of the A rkoma B asin Province and geologically related areas: U.S. Geological Survey Fact Sheet 2010-3043, 4 p. Available at http://pubs.usgs.gov/ fs/2010/3043/.

Houseknecht, D.W., Rouse, W.A., Garrity, C.P., Whidden, K. J. , Dumoulin, J.A., Schenk, C.J., Charpentier, R.R., Cook, T.A., Gaswirth, S.B., Kirschbaum, M.A., and Pollastro, R.M., 2012, Assessment of potential oil and gas resources in source rocks of the Alaska North Slope, 2012: U.S. Geological Survey Fact Sheet 2012-3013, 2 p. Available at http://pubs.usgs.gov/fs/2012/3013/.

IHS Energy, 2012, PI/Dwights PLUS on CD: IHS Energy, Littleton, Colo., ver. 1.7, v. 22, issue 3. Current as of Feb. 2012.

Janssens, Adriaan, and deWitt, Wallace, Jr., 1976, Potential natural gas resources in the Devonian shales of Ohio: Geological Note no. 3. State of Ohio, Department of Natural Resources, Division of Geological Survey, Columbus, Ohio, $12 \mathrm{p}$.

Kirschbaum, M.A., Schenk, C.J., Cook, T.A., Ryder, R.T., Charpentier, R.R., Klett, T.R., Gaswirth, S.B., Tennyson, M.E., and Whidden, K.J., 2012, Assessment of undiscovered oil and gas resources of the Ordovician Utica Shale of the Appalachian Basin Province, 2012: U.S. Geological Survey Fact Sheet 2012-3116, 6 p. Available at http://pubs.usgs.gov/ fs/2012/3116/.

K uuskraa, Vello, and Stevens, Scott, 2009, Lessons learned help optimize development: Oil \& Gas Journal, October 5, 2009 , p. 52-57.
Longman, M.W, Luneau, B.A., and Landon, S.M., 1998, $\mathrm{N}$ ature and distribution of Niobrara lithologies in the Cretaceous Western Interior Seaway of the Rocky Mountain Region: The Mountain Geologist, v. 35, no. 4., Oct. 1998, p. 137-170.

Martineau, D.F., 2007, History of the Newark East field and the $B$ arnett Shale as a gas reservoir: A merican A ssociation of Petroleum Geologists Bulletin, v. 91, no. 4, April 2007, p. 399-403.

Milici, R.C., Ryder, R.T., Swezey, C.S., Charpentier, R.R., Cook, T.A., Crovelli, R.A., Klett, T.R., Pollastro, R.M., and Schenk, C.J ., 2003, A ssessment of undiscovered oil and gas resources of the A ppalachian B asin Province, 2002: U.S.

Geological Survey Fact Sheet FS-009-03, 4 p. Available at http://pubs.usgs.gov/fs/fs-009-03/.

Milici, R.C., and Swezey C.S., 2006, Assessment of Appalachian basin oil and gas resources: Devonian shale-M iddle and Upper Paleozoic Total Petroleum System: U.S. Geological Survey Open-File Report 2006-1237. Available at http://pubs.usgs.gov/of/2006/1237/.

Pollastro, R.M., Hill, R.J., Ahlbrandt, T.A., Charpentier, R.R., Cook, T.A., Klett, T.R., Henry, M.E., and Schenk, C.J., 2004b, A ssessment of undiscovered oil and gas resources of the Bend arch- Fort Worth basin province of north-central Texas and southwestern Oklahoma, 2003, U.S. Geological Survey Fact Sheet 2004-3022, 2 p. Available at http://pubs.usgs.gov/ fs/2004/3022/.

Pollastro, R.M., 2007, Total petroleum system assessment of undiscovered resources in the giant B arnett Shale continuous (unconventional) gas accumulation, Fort Worth B asin, Texas: American Association of Petroleum Geologists Bulletin, v. 91; no. 4; p. 551-578. Accessed on May 12, 2010 at http://aapgbull.geoscienceworld.org/cgi/content/ full/91/4/551.

Railroad Commission of Texas, 2010b, Haynesville/Bossier shale information: Austin, Railroad Commission of Texas. Accessed on May 12, 2010 at http://www.rrc.state.tx.us/ bossierplay/index.php.

Roen, J.B., and Walker, B.J., eds., 1996, The atlas of major A ppalachian gas plays: funded by U.S. D epartment of Energy, compiled primarily by partners of the A ppalachian Oil and Natural Gas Research Consortium (State Geological Surveys of Kentucky, Ohio, Pennsylvania, and West Virginia, and the University of West Virginia).

Ryder, R.T., 2008, Assessment of Appalachian basin oil and gas resources-Utica-Lower Paleozoic Total Petroleum System: U.S. Geological Survey Open-File Report 2008-1287, 29 p. Available at http://pubs.usgs.gov/ of/2008/1287. 
Schenk, C.J., Pollastro, R.M., Cook, T.A., Pawlewicz, M.J., Klett, T.R., Charpentier, R.R., and Cook, H.E., 2008, A ssessment of undiscovered oil and gas resources of the Permian Basin Province of west Texas and N ew M exico, 2007: U.S. Geological Survey Fact Sheet FS-2007-3115, 4 p. Available at http://pubs.usgs.gov/fs/2007/3115/.

Schruben, P.G., Arndt, R.E., and Bawiec, 1994, Geology of the Conterminous United States at 1:2,500,000 Scale-A Digital Representation of the 1974 P.B. King and H.M. Beikman Map: U.S. Geological Survey Digital Data Series DDS-11, release 2 .

Shurr, G.W., 2008, Shallow biogenic gas in Cretaceous shale on the eastern margin of the Williston Basin, in Hill, D., Lillis, P., and Curtis, J., eds., Gas Shale in the Rocky Mountains and Beyond, 2008 Guidebook: Rocky Mountain Association of Geologists, p. 176-198.

Stevens, Scott and Kuuskraa, Vello, 2009, Special Report: Gas Shale 1 - Seven plays dominate North America activity: Oil \& Gas Journal, September 28, 2009, p. 39-49. Accessed on July 9, 2012 at http://www.ogj.com/articles/print/volume-107/ issue-36/D rilling___P roduction/special-report-gas-shale-1seven-plays-dominate-north-america-activity.html.

Swezey, C.S., Hatch, J.R., Hayba, D.O. , Repetski, J.E., Charpentier, R.R., Cook, T.A., Klett, T.R., Pollastro, R.M., and Schenk, C.J., 2005, Assessment of undiscovered oil and gas resources of the U.S. portion of the M ichigan basin, 2004: U.S. Geological Survey Fact Sheet 2005-3070. Available at http://pubs.usgs.gov/fs/2005/3070/2005-3070.pdf.

Swezey, C.S., Hatch, J.R., Brennan, S.E., East, J.A., Rowan, E.L., Repetski, J.E., Charpentier, R.R., Cook, T.A., Klett, T.R., Pollastro, R.M., and Schenk, C.J., 2007, Assessment of undiscovered oil and gas resources of the Illinois basin, 2007: U.S. Geological Survey Fact Sheet FS 2007-3058, 2 p. Available at http://pubs.usgs.gov/fs/2007/3058/ fs2007-3058.pdf.

USGS Marcellus Shale Assessment Team, 2011, Information relevant to the U.S. Geological Survey assessment of the M iddle Devonian Shale of the A ppalachian Basin Province, 2011: U.S. Geological Survey Open-File Report 2011-1298, 22 p. Available at http://pubs.usgs.gov/of/2011/1298/.

Whidden, K.J., 2012, Assessment of undiscovered oil and gas resources in the Paradox B asin Province, U tah, Colorado, New Mexico, and Arizona, 2011: U.S. Geological Survey Fact Sheet 2012-3031, 4 p. Available at http://pubs.usgs.gov/ fs/2012/3031/F S12-3031. pdf.

\section{Selected References Uncited}

A bouel resh, M.0., 2009, Core characteristics of the Barnett Shale in part of the Fort Worth basin, Texas, USA, in Petroleum Technology Transfer Council/Rocky Mountain Association of Geologists Unconventional reservoirs core workshop, Dec. 3, 2009: Rocky Mountain Association of Geologists.

Arkansas Geological Survey, 2007, Fayetteville Shale gas: Arkansas Geological Survey. Accessed on May 12, 2010 at http://www.geology.ar.gov/energy/natural_gas.htm.

Arkansas Oil and Gas Commission, 2010, Fayetteville Shale information: Little Rock, State of Arkansas Oil and Gas Commission. Accessed on June 26, 2012 at http://www.aogc.state.ar.us/F ay_Shale_Data.htm.

Arthur, J.D., Bohm, B rian, Coughlin, B.J ., and Layne, M ark, Ph.D., 2008, Hydraulic fracturing considerations for natural gas wells of the Fayetteville Shale: Tulsa, Okla., AL L Consulting. Accessed on June 26, 2012 at http://www.all-IIc.com/ publicdownloads/ALLF ayettevilleF racF INAL.pdf.

A rthur, J.D., B ohm, B rian, and Layne, M ark, 2009, Completion/stimulation technology - Considerations for development of M arcellus Shale gas: World Oil online, July 2009, p. 65-69.

Avary, K.L., and Lewis, J.E., 2008, New interest in cores taken thirty years ago- The Devonian M arcellus Shale in northern West Virginia, in A merican A ssociation of Petroleum Geologists, Eastern Section Meeting, Pittsburgh, Pennsylvania 2008: A merican A ssociation of Petroleum Geologists, Eastern Section. Accessed on May 12, 2010 at http://www.searchanddiscovery.net/ documents/2008/08167eastern_abs/abstracts/avary.htm.

Ayers J r., W.B ., 2002, Coal bed gas systems, resources, and production and a review of contrasting cases from the San Juan and Powder River basins: American Association of Petroleum Geologists Bulletin, v. 86, no. 11, p. 1853-1890.

Ball, M.M., and Perry, W.J., 1996, Bend arch-Fort Worth basin province (045), in Gautier, D.L., Dolton, G.L., Takahashi, K.I., and Varnes, K. L., eds., 1995 National assessment of United States oil and gas resources-Results, methodology, and supporting data: U.S. Geological Survey Digital Data Series DDS-30, release 2. A ccessed on May 12, 2010 at http://certmapper.cr.usgs.gov/data/noga95/ prov45/text/prov45.pdf.

Barrows, M.H., and Cluff, R.M., 1984, New Albany Shale group (D evonian-M ississippian) source rocks and hydrocarbon generation in the Illinois B asin, in G. Demaison and Murris, R.J., eds., Petroleum geochemistry and basin evaluation: American Association of Petroleum Geologists Memoir no. 35, p. 111-138. 
B eaubouef, B ruce, 2009, B arnett Shale transportation capacity largely in place, PipeLine and Gas Technology: Houston, Tex., Hart Energy, M idStream B usiness. com. A ccessed on May 12, 2010 at http://www.pipelineandgastechnology.com/ Construction/F orecastsR eviews/item55705.php.

B erman, A rthur, 2009, Lessons from the B arnett Shale suggest caution in other shale plays, in A ssociation for the Study of Peak Oil and Gas-USA: Washington, D.C., Association for the Study of Peak Oil and Gas USA, . Accessed on May 12, 2010 at http://www. aspousa. org/index. php/2009/08/lessonsfrom-the-barnett-shale-suggest-caution-in-other-shale-plays/.

B erman, A rthur, 2009b, W hat's new in exploration-A long recovery for gas prices-Revisiting the Haynesville shale: World Oil online, June 2009, p. 15.

Bowker, K.A., 2002, Recent developments of the Barnett Shale play, Fort Worth basin, in Law, B.E., and M. Wilson, eds., Innovative Gas Exploration Concepts Symposium: Rocky Mountain Association of Geologists and Petroleum Technology Transfer Council, October, 2002, Denver, Colorado: Rocky Mountain Association of Geologists, 16 p.

Bowker, K.A., 2003, Recent developments of the Barnett Shale play, Fort Worth basin: West Texas Geological Society Bulletin, v. 42, no. 6, p. 4-11.

B owker, K.A., 2007, Barnett Shale gas production, Fort Worth basin: Issues and discussion, in A merican A ssociation of Petroleum Geologists Bulletin, v. 91, no. 4, p. 523-533. Accessed on May 12, 2010 at http://aapgbull.geoscienceworld.org/cgi/ content/full//91/4/523.

Boyd, D.T., 2009, Oklahoma 2008 drilling highlights: The Shale Shaker, Oklahoma Geological Survey, March-April 2009. Accessed on May 12, 2010 at http://www.ogs.ou.edu/ pdf/2008-D rillingH ighlights.pdf.

Brittenham, M.D., 2009, Gas shale mega-plays, a challenge for the Rockies, in Kelso, B.S., and Lamarre, R.A., chairmen, Unconventional Reservoirs, Oil and Gas Shales and CBM Symposium, Rocky Mountain Association of Geologists and Petroleum Technology Transfer Council, Denver, Colo., Sept. 14, 2009: Rocky Mountain Association of Geologists and Petroleum Technology Transfer Council.

Brown, David, 2006, Shales require creative approaches: American Association of Petroleum Geologists Explorer, v. 27 , no. 11 .

Brown, David, 2007, From sea to shining sea, if it's shale, it's probably in play: American Association of Petroleum Geologists Explorer: American Association of Petroleum Geologists. Accessed on May 12, 2010 at http://www.aapg.org/ explorer/2007/04apr/beyond_barnett.cfm.

Bullin, K.A ., and K rouskop, P.E., 2009, Compositional variety complicates processing plans for U.S. shale gas: Oil \& Gas Journal, v. 107, issue 10, special report.

Byers, C.W., 1977, Biofacies patterns in euxinic basins-A general model, in Cook, H.E., and Enos, P., eds., Deepwater carbonate environments: Society of E conomic Paleontologists and Mineralogists Special Publication 25, p. 5-17.
Caramanica, F.P., 1988, Oil and gas report and maps of K anawha and B oone counties, West Virginia: West Virginia Geological and Economic Survey, Bulletin B-19A, 115 p.

Cardott, B.J., 2004, Overview of unconventional energy resources of Oklahoma, Oklahoma Geological Survey Conference on Unconventional Energy Resources in the Southern M idcontinent, O klahoma City, Oklahoma, March 9, 2004: Oklahoma Geological Survey. Accessed on May 12, 2010 at http://www.ogs.ou.edu/fossilfuels/coalpdfs/ Unconventional P resentation.pdf .

Cardott, B.J., 2008, Overview of Woodford gas-shale play of Oklahoma, U.S.A .: A merican A ssociation of Petroleum Geologists Annual Convention, San Antonio, Texas: American Association of Petroleum Geologists, AAPG Search and Discover article 90078. Accessed on May 12, 2010 at http://www.searchanddiscovery.net/abstracts/html/2008/ annual/abstracts/409566.htm.

Cardott, B.J., 2009a, Woodford gas-shale plays of Oklahoma, Louisiana oil and gas symposium, M ay 20, 2009: O klahoma Geological Survey. Accessed on May 12, 2010 at http://www.ogs.ou.edu/fossilfuels/pdf/LAoilgas2009.pdf.

Cardott, B.J., 2009b, Application of vitrinite reflectance to the Woodford gas-shale play in O klahoma, A merican A ssociation of Petroleum Geologists Mid-continent section meeting, October 12, 2009: American Association of Petroleum Geologists. Accessed on May 12, 2010 at http://www.ogs.ou.edu/ fossilfuels/pdf/2009AAPG_MC_Shale.pdf.

Cardott, B .J ., Avary, K.L., B owker, K .A ., Chidsey, T.C., J r., Harrison, W.B., III, M cCracken, J.N., M organ, C.D., and Tabet, D.E., 2009, Gas shale, in Unconventional energy resources, 2007-2008 review: A merican A ssociation of Petroleum Geologists, Energy Minerals Division, published online: April 17, 2009. Accessed on May 12, 2010 at http://www.mdcampbell.com/EM D_AAPG_2009_NRR.pdf

Carr, J.L., III, 1987, The thermal maturity of the Chattanooga Formation along a transect from the Ozark uplift to the Arkoma basin: The Shale Shaker, Oklahoma Geological Survey, p. 32-40.

Carroll, R.E., Pashin, J.C., and Kugler, R.L., 1995, Burial history and source-rock characteristics of U pper Devonian through Pennsylvanian strata, Black Warrior basin, A labama: Alabama Geological Survey Circular 187, 29 p.

CER Corporation, 1992, Geological, petrophysical and engineering analysis of the Barnett Shale in the M itchell Energy Corporation T.P. Sims No. 2, Wise County, Texas: Gas Research Institute contract report no. 5091-212-2242, 83 p.

Cercone, K.R., 1984, Thermal history of Michigan basin: American Association of Petroleum Geologists Bulletin, v. 68 , no. 2 , p. $130-136$.

Cercone, K.R., and Pollack, H.N., 1991, Thermal maturity of the M ichigan basin, in Catacosinos, P.A., and Daniels, P, A., eds, Early sedimentary evolution of the M ichigan basin: Geological Society of America Special Paper 256, p. 1-11. 
Charpentier, R.R., deWitt, Wallace, Jr., Claypool, G.E., Harris, L.D., Mast. R.F., Megeath, J.D., Roen, J.B., and Schmoker, J.W., 1993, Estimates of unconventional natural gas resources in the Devonian shales of the A ppalachian basin, in Roen, J.B., and Kepferle, R.C., eds., Petroleum geology of the D evonian and M ississippian black shale of eastern North America: U.S. Geological Survey Bulletin 1909, p. N1-N20.

Cluff, R.M., 1980, Paleoenvironment of the New Albany Shale group (Devonian-M ississippian) of Illinois: J ournal of Sedimentary Petrology, v. 50, no. 3, p. 767-780. Accessed on May 12, 2010 at http://jsedres.geosciencew 0 rld.org/cgi/ reprint/50/3/767.pdf.

Cluff, R.M., Reinbold, M.L., and Lineback, J.A., 1981, The New Albany Shale group of Illinois: Illinois State Geological Survey Circular 518, 83 p.

Comer, J.B., Hasenmueller, N.R., Mastalerz, M.D., Rupp, J.A., Shaffer, N.R., and Zuppann, C.W., 2006, The New Albany Shale gas play in southern Indiana, Program with abstracts, American Association of Petroleum Geologists, Eastern Section, 35th Annual Meeting, Oct., 8-11, 2006, Buffalo, New York: American Association of Petroleum Geologists, Eastern Section, p. 17. Accessed on M ay 12, 2010 at https://scholarworks.iu.edu/dspace/handle/2022/712.

Comer, J.B., 2008, Reservoir characteristics and production potential of the Woodford Shal e: World Oil online. Accessed on May 12, 2010 at http://www.worldoil.com/ August-2008-Reservoir-characteristics-and-productionpotential-of-the-Woodford-Shale.html.

Conant, L.C., and Swanson, V.E., 1961, Chattanooga Shale and related rocks of central Tennessee and nearby areas: U.S. Geological Survey Professional Paper 357, 109 p. Available at http://pubs.usgs.gov/pp/0357/report.pdf.

D'A gostino, Tony, 2008, A ge, sequences, depo-models, and biofacies-U.S. Mississippian shale-gas basins, Rocky Mountain Section of the Society for Sedimentary Geology March lunch meeting, March 25, 2008, Denver Colo: Rocky Mountain Section of the Society for Sedimentary Geology. Accessed on May 12, 2010 at http://rmssepm.org/pdfs/ DagostinoF eb2008.pdf.

Dawson, W.C., 2000, Shale microfacies-Eagle Ford Group (Cenomanian-Turonian) north-central Texas outcrops and subsurface equivalents: Gulf Coast Association of Geological Societies Transactions, v. 50, p. 607-621.

Decker, A.D., Coates, J-M.P., and Wicks, D.E., 1992, Stratigraphy, gas occurrence, formation evaluation and fracture characterization of the Antrim Shale, Michigan basin: Gas Research Institute Topical Report GRI-92/0258, 101 p.

Dellapenna, T.M., 1991, Sedimentological, structural, and organic geochemical controls on natural gas occurrence in the A ntrim Formation in O tsego County, M ichigan: K alamazoo, Western Michigan University, M.S. thesis, 147 p.
deWitt, Wallace, Jr., Roen, J.B., and Wallace, L.G., 1993, Stratigraphy of Devonian black shales and associated rocks in the A ppalachian basin, in Roen, J.B., and Kepferle, R.C., eds., Petroleum geology of the Devonian and M ississippian black shale of eastern North America: U.S. Geological Survey Bulletin 1909, p. B1-B57.

Durham, L.S., 2009b, No Recession for the Haynesville: American Association of Petroleum Geologists Explorer, July 2009 issue. Accessed on July 9, 2012 at http://www. aapg.org/explorer/2009/07jul/haynesville0709.cfm.

Durham, L.S., 2009c, Haynesville vs. Barnett-Is my shale better than your shale?: A merican A ssociation of Petroleum Geologists Explorer, Sept. 2009 issue. Accessed on July 9, 2012 at http://www.aapg.org/explorer/2009/09sep/ shale0909.cfm.

Durham, L.S., 2010, Eagle Ford joins shale elite: American Association of Petroleum Geologists Explorer, Jan. 2010 issue. Accessed on May 12, 2010 at http://www.aapg.org/ explorer/2010/01jan/eagleford0110.cfm.

Engelder, Terry, and Lash, G.G., 2008, Marcellus Shale play's vast resource potential creating stir in A ppalachia: Derby, Kan., National Publishers Group Inc., The American Oil \& Gas Reporter, May 2008 issue. Accessed on May 12, 2010 at http://www.wpsu.org/gasrush/assets/pdfs/M arcellus_ Shale_Play_May08.pdf.

Ettensohn, F.R., 1985, Controls on the development of Catskill Delta complex basin-facies: Geological Society of America Special Paper 201, p. 65-77.

Ettensohn, F.R., Lierman, R.T., and Mason, C.E., 2009, Upper Devonian-L ower M ississippian clastic rocks in northeastern K entucky- Evidence for A cadian al pine glaciation and models for source-rock and reservoir-rock development in the eastern U nited States: A merican Institute of Professional Geologists, Kentucky Section Spring field guide, April 18, 2009.

Filer, J.K., 1985, Oil and gas reports and maps of Pleasants, Wood, and Ritchie counties, West Virginia: West Virginia Geological and Economic Survey Bulletin B-11A, 87 p.

Fishman, Neil, Ellis, Geoffrey, Paxton, Stanley, Abbott, Marvin, and B oehlke, A dam, 2009, M ineral and organic carbon heterogeneity in the U pper D evonian-L ower M ississippian Woodford Shale, A nadarko Basin, O klahoma- Implications for a World-class shale-gas system [abs], in A merican Association of Petroleum Geologists Annual Convention and Exhibition, June 7-10, 2009, Denver, Colo: American Association of Petroleum Geologists.

Gardner, W.C., and Bray, E.E., 1984, Oils and source rocks of Niagaran reefs (Silurian) in the M ichigan Basin, in Palacas, J.G., ed., Petroleum geochemistry and source rock potential of carbonate rocks: A merican A ssociation of Petroleum Geologists Studies in Geology 18, p. 33-44. 
Geological Survey of Alabama, 2008, Gas shale research, geological foundation for production of natural gas from diverse shale formations: Geological Survey of Alabama. Accessed on May 12, 2010 at http://www.gsa.state.al.us/ gsa/shalegas.html.

Givens, Natalie, and Zhao, Hank 2004, The Barnett Shalenot so simple after all [abs.]: A merican A ssociation of Petroleum Geologists Annual Meeting Program, v. 13, p. A52.

Hackley, P.C., Dennen, Kristin, Gesserman, Rachel, and Ridgley, J. L., 2009, Preliminary investigation of the thermal maturity of Pearsall Formation shales in the M averick basin, South Texas, A merican A ssociation of Petroleum Geologists Annual Convention and Exhibition, Denver, Colo., June 7-10, 2009: American Association of Petroleum Geologists Search and Discovery Article \#90090. Accessed on May 12, 2010 at http://www.searchanddiscovery.net/ abstracts/html/2009/annual/abstracts/hackley.htm.

Hamilton-Smith, Terence, 1993, Gas exploration in the Devonian shales of Kentucky: Kentucky Geological Survey Series 11, Bulletin 4, $31 \mathrm{p}$.

Hammes, U rsula, and Carr, D.L., 2009, Sequence stratigraphy, depositional environments, and production fairways of the Haynesville shale-gas: A merican A ssociation of Petroleum Geologists, Search and Discovery Article 110084. Accessed on May 12, 2010 at http://www.searchanddiscovery.com/ documents/2009/110084hammes/ndx_hammes.pdf.

Hancock, J.M., 1993, Sea-level changes around the Cenomanian-Turonian boundary: Cretaceous Research, v. 14, p. 553-562.

Harper, J.A., 1999, Devonian, in Schultz, C.H., ed., The geology of Pennsylvania, chap. 7,: Pennsylvania Bureau of Topographic and Geologic Survey Special Publication 1, p. 108-127.

Harris, N ate, 2009, Unconventional approach unlocks unconventional gas play: Hart Energy, E\&P Magazine.

Harris, N .B., Hemmesch, N.T., M nich, C.A ., A oudia, K hodir, and $M$ iskimins, J ennifer, 2009, A n integrated geological and petrophysical study of a shale gas play-Woodford Shale, Permian Basin, west Texas: Gulf Coast Association of Geological Societies Transactions, v. 59, p. 337-346. Accessed on May 12, 2010 at http://www.searchanddiscovery.net/ abstracts/html/2009/gcags/abstracts/harris.htm.

Hasenmueller, N.R., 1993, New Albany Shale (Devonian and $\mathrm{M}$ ississippian) of the Illinois Basin, in Roen, J.B., and Kepferle, R.C., eds., Petroleum geology of the Devonian and $\mathrm{M}$ ississippian black shale of eastern N orth A merica: U.S. Geological Survey Bulletin 1909, p. C1-C19.

Hasenmueller, N.R., and Comer, J.B., 1994, Gas potential of the New A lbany Shale (Devonian and M ississippian) in the Illinois basin: Gas Research Institute Topical Report GRI-92/0391, 83 p.

Hasenmueller N.R., and Leininger R.K., 1987, Oil shale prospects for the N ew A Ibany Shale in Indiana: Indiana Geological Survey, Special Report 40.
Henk, F., B reyer, J., and Jarvie, D.M., 2000, Lithofacies, petrology, and geochemistry of the Barnett Shale in conventional core and B arnett Shale outcrop geochemistry [abs.], in L. B rogden, ed., B arnett Shale Symposium, Fort Worth Texas: Oil Information Library of Fort Worth, p. 7.

Hill, D.G., and Nelson, C.R., 2000, Gas productive fractured shales-An overview and update: GasTIPS, v. 6, no. 2, p. 4-13.

Holst, T.B., and Foote, G.R., 1981, Joint orientation in Devonian rocks in the northern portion of the lower peninsula of Michigan: Geological Society of America Bulletin, v. 92, no. 2, p. 85-93.

Hosterman, J.W., 1993, Illite crystallinity as an indicator of the thermal maturity of Devonian black shales in the A ppalachian Basin, in Roen, J.B., and Kepferle, R.C., eds., Petroleum geology of the Devonian and M ississippian black shale of eastern North America: U.S. Geological Survey Bulletin 1909, p. G1-G9.

Houseknecht, D.W., and Bird, K.J., 2004, Sequence stratigraphy of the K ingak Shale (J urassic-L ower Cretaceous), National Petroleum Reserve in Alaska: American Association of Petroleum Geologists Bulletin, v. 88, p. 279-302. Accessed on May 12, 2010 at http://doi.aapg.org/data/ bulletns/2004/03mar/0279/0279.htm.

Hunter, C.D., and Young, D.M., 1953, Relationship of natural gas occurrence and production in eastern K entucky (Big Sandy gas field) to joints and fractures in Devonian bituminous shales: American Association of Petroleum Geologists Bulletin, v. 37, no. 2, p. 282-299.

IHS Energy, 2008, IHS PIDM Well and Production Oracle Database: IHS Energy, Littleton, Colo.

IHS Energy, 2011, PI/Dwights PLUS on CD: IHS Energy, Littleton, Colo., ver. 1.7, v. 21, issue 4, current as of March 2011.

Jarvie, D.M., Claxton, B.L., Henk, F., and Breyer, J.T., 2001, Oil and shale gas from the B arnett Shale, Ft. Worth basin, Texas [abs.]: American Association of Petroleum Geologists A nnual M eeting, Program with A bstracts: A merican Association of Petroleum Geologists, p. A100.

Jarvie, D.M., Hill, R.J., Pollastro, R.M., Wavrek, D.A., Bowker, K.A., Claxton, B. L., and Tobey, M.H., 2003, Evaluation of unconventional natural gas prospects-The B arnett Shale fractured shale gas model [abs.], E uropean Association of International Organic Geochemists Meeting, Krakow, Poland, September 8-12: European Association of Organic Geochemists, 1 p.

Jarvie, D.M., Hill, R.J., and Pollastro, R.M., 2005, Assessment of the gas potential and yields from shales- The B arnett Shale model, in B. J. Cardott, ed., Unconventional energy resources in the southern midcontinent, 2004 symposium: Oklahoma Geological Survey Circular 110, p. 37-50. 
Jarvie, D.M., Hill, R.J., Ruble, T.E., and Pollastro, R.M., 2007, Unconventional shale-gas systems-The M ississippian Barnett Shale of north-central Texas as one model for thermogenic shale-gas assessment: A merican A ssociation of Petroleum Geologists Bulletin, v. 91, no. 4, p. 475-499. Accessed on May 12, 2010 at http://aapgbull.geoscienceworld.org/cgi/ content/full/91/4/475.

Kepferle, R.C., 1993, A depositional model and basin analysis for the gas- bearing black shale (Devonian and M ississippian) in the A ppalachian B asin, in Roen, J.B., and Kepferle, R.C., eds., Petroleum geology of the Devonian and Mississippian black shale of eastern North America: U.S. Geological Survey Bulletin 1909, p. F1-F23.

K inley, T.J., Cook, L.W., B reyer, J .A., Jarvie, D.M., and B usbey, A.B ., 2008, Hydrocarbon potential of the B arnett Shale (M ississippian), Delaware basin, west Texas and southeastern New M exico: A merican A ssociation of Petroleum Geologists Bulletin, v. 92; no. 8; p. 967-991. Accessed on May 12, 2010 at http://aapgbull.geosciencew orld.org/cgi/ content/full/92/8/967.

Kupecz, J.A., 1995, Depositional setting, sequence stratigraphy, diagenesis, and reservoir potential of a mixed-lithology, upwelling deposit- The Upper Triassic Shublik Formation, Prudhoe B ay, A laska: A merican A ssociation of Petroleum Geologists Bulletin, v. 79, p. 1301-1319. Accessed on May 12, 2010 at http://doi.aapg.org/data/ bulletns/1994-96/images/pg/00790009/1300/1301.pdf.

Lewan, M.D., Henry, M .E., K igley, D.K., and Pitman, J .K., 2002, M aterial-balance assessment of the New A lbanyChesterian petroleum system of the Illinois B asin: A merican Association of Petroleum Geologists Bulletin, v. 86, p. 745-777.

Liro, L.M., Dawson, W.C., Katz, B.J., and Robison, V.D., 1994, Sequence stratigraphic elements and geochemical variability within a "condensed section"-Eagle Ford Group, east-central Texas: Gulf Coast Association of Geological Societies Transactions, v. 44, p. 393-402.

Loucks, R.G., and Ruppel, S.C., 2007, Mississippian Barnett Shale- Lithofacies and depositional setting of a deep-water shale-gas succession in the Fort Worth Basin, Texas: A merican Association of Petroleum Geologists Bulletin, v. 91, no. 4, p. 579-601. Accessed on May 12, 2010 at http:// aapgbull.geoscienceworld.org/cgi/content/full/91/4/579/.

Macke, D.L., 1996, Illinois Basin Province (064), in Gautier, D. L., Dolton, G.L., Takahashi, K.I., and Varnes, K.L., eds., 1995 National assessment of United States oil and gas resources - Results, methodology, and supporting data: U.S. Geological Survey Digital Data Series DDS-30, release 2. Accessed on May 12, 2010 at http://certmapper.cr.usgs.gov/ data/noga95/prov64/text/prov64.pdf.

M artini, A.M ., Walter, L .M ., B udai, J .M ., K u, T.C.W., K aiser, C.J., and Schoell, M., 1998, Genetic and temporal relations between formation waters and biogenic methane-U pper Devonian Antrim Shale, Michigan basin, USA: Geochimica et Cosmochimica Acta, v. 62, no. 10, p. 1699-1720.
Matthews, R.D., 1993, Review and revision of the Devonian$\mathrm{M}$ ississippian stratigraphy in the M ichigan Basin, in Roen, J.B., and Kepferle, R.C., eds., Petroleum geology of the Devonian and M ississippian black shale of eastern North America: U.S. Geological Survey Bulletin 1909, p. D1-D85.

Maynard, J.B., 1981, Some geochemical properties of the Devonian-Mississippian shale sequence, Kepferle, R.C., and Roen, J.B., Field trip 3, Chattanooga and Ohio Shales of the southern A ppalachians, in Roberts, T. G., ed., Field trip guidebooks for the annual meeting of the Geological Society of America, 1981, Cincinnati, Ohio, v. 2-Economic geology, structure: Falls Church, American Geological Institute, p. 336-343.

M clntosh, J.C., Walter, L.M ., and M artini, A .M ., 2002, Pleistocene recharge to $\mathrm{M}$ idcontinent basins- effects on sal inity structure and microbial gas generation: Geochimica et Cosmochimica Acta, v. 66, no. 10, p. 1681-1700.

Milici, R.C., 1993, Autogenic gas (self-sourced) from shales- A n example from the A ppalachian basin, in Howell, D.G., ed., The future of energy gases: U.S. Geological Survey Professional Paper 1570, p. 253-278.

Milici, R.C., 1996a, Devonian black shale gas plays, in Gautier, D.L., Dolton, G.L., Takahashi, K.I., and Varnes, K.L., eds., 1995 National assessment of United States oil and gas resources - Results, methodology, and supporting data: U.S. Geological Survey Digital Data Series 30, release 2, p. 57-60. Accessed on May 12, 2010 at http://certmapper.cr.usgs.gov/data/noga95/prov67/text/ prov67.pdf.

Milici, R.C., 1996b, Upper Devonian fractured black and gray shales and siltstones, in Roen, J.B. and Walker, B.J., eds., 1996, The Atlas of Major Appalachian Gas Plays: The Appalachian Oil and Natural Gas Research Consortium, Western Virginia Geological and Economic Survey V-25, $201 \mathrm{p}$.

M ontgomery, S.L., Jarvie, D.M., Bowker, K .A., and Pollastro, R.M., 2005, Mississippian Barnett Shale, Fort Worth Basin-North-central Texas: Gas-shale play with multi-tcf potential: American Association of Petroleum Geologists Bulletin, v. 89, p. 155-175. Accessed on May 12, 2010 at http://aapgbull.geoscienceworld.org/cgi/content/ full/89/2/155/.

Mortis, G., 2004, Horizontal wells show promise in Barnett Shale: Oil \& Gas Journal, p. 58.

Nyahay, Richard, Leone, James, Smith, L.B., Martin, J.P., and Jarvie, D.J ., 2007, U pdate on regional assessment of gas potential in the Devonian M arcellus and U tica Shales of N ew Y ork, Eastern Section, A merican A ssociation of Petroleum Geologists Annual Meeting Program with Abstracts, Sept. 16-18, 2007, Lexington, Ken.: American Association of Petroleum Geologists, p. 46.

Oil and Gas Journal editors, 2010, Enterprise, Duncan to expand Eagle Ford plants: Oil \& Gas Journal, May 13, 2010 issue. 
Oil and Gas Journal editors, 2009a, Eagle Ford viewed among top US shale gas plays: Oil \& Gas Journal, May 4, 2009 issue.

Oil and Gas Journal editors, 2009b, Haynesville buried-array seismic work set: Oil \& Gas Journal, Nov. 18, 2009 issue.

Oil and Gas Journal editors, 2009c, Devon to accelerate Haynesville shale drilling: Oil \& Gas Journal, Nov. 18, 2009 issue.

Oil and Gas Journal editors, 2009d, Kinder Morgan plans Eagle Ford Shale pipeline project: Oil \& Gas Journal, N ov. 20, 2009 issue.

Parrish, J.B., 2008, Shale we look for gas?, State Geologist's editorial: Pennsylvania Geology, v. 38, no. 1.

Parrish, J.T., 1987, Lithology, geochemistry, and depositional environment of the Shublik Formation (Triassic), northern A laska, in Tailleur, I.L., and Weimer, P., eds., A laskan N orth Slope Geology, v. 1: Society for Sedimentary Geology Pacific Section, Anchorage, Alaska, and the Alaska Geological Society, p. 391-396.

Parrish, J.T., Droser, M.L., and Bottjer, D.J., 2001, A Triassic upwelling zone - the Shublik Formation, Arctic Alaska: Journal of Sedimentary Research, v. 71, p. 272-285.

Pashin, J.C., 2008, Gas shale potential of Alabama, 2008 International Coalbed \& Shale Gas Symposium Proceedings, B ryant Conference Center, The U niversity of A labama, Tuscaloosa, A la., USA, paper 0808: Tuscal oosa, A la., U niversity of Alabama, College of Continuing Studies, $13 \mathrm{p}$.

Pashin, J.C., 2009, Shale gas plays of the southern A ppalachian thrust belt, 2009 International Coalbed \& Shale Gas Symposium Proceedings, paper 0907: Tuscaloosa, A labama, University of Alabama, College of Continuing Studies, $14 \mathrm{p}$. Accessed on May 12, 2010 at http://www.gsa.state.al.us/img/ shale/0907\% 20Pashin.pdf.

Patchen, D.G., and Hohn M.E., 1993, Production and production controls in Devonian shales, West Virginia, in Roen, J.B., and Kepferle, R.C., eds., 1993, Petroleum geology of the Devonian and M ississippian black shale of eastern North America: U.S. Geological Survey Bulletin 1909B, p. L1-L28.

Pawlewicz, M.J., and Hatch, J.R., 2007, Petroleum assessment of the Chattanooga Shale/Floyd Shale-Paleozoic Total Petroleum System, B lack Warrior B asin, A labama and M ississippi, in Hatch, J.R., and Pawlewicz, M.J., compilers, Geologic assessment of undiscovered oil and gas resources of the Black Warrior Basin Province, A labama and M ississippi: U.S. Geological Survey Digital Data Series 69-I, chap. 3, 23 p. Available at http://pubs.usgs.gov/dds/dds-069/ dds-069-i/REPORTS/69_I_CH_3.pdf.

Perez, John, 2008, Shale horizontal drilling: John Perez Graphics \& Design, LLC. Accessed on June 26, 2012 at http://www.geoart.com/onshore_schematics.php.
Peters, K.E., Magoon, L.B., Bird, K.J., Valin, Z.C., and Keller, M.A., 2006, North Slope Alaska-Source-rock distribution, richness, thermal maturity and petrol eum charge: American Association of Petroleum Geologists Bulletin, v. 90, no. 2, p. 261-292. Accessed on May 12, 2010 at http://aapgbull.geoscienceworld.org/content/90/2/261.full.pdf.

Pollastro, R.M., 2003, Geological and production characteristics utilized in assessing the Barnett Shale continuous (unconventional) gas accumulation, Barnett-Paleozoic total petroleum system, Fort Worth basin, Texas, B arnett Shale Symposium, Ellison Miles Geotechnology Institute at Brookhaven College, Dallas, Texas, Nov. 12-13, 2003: Ellison Miles Geotechnology Institute at Brookhaven College, $6 \mathrm{p}$.

Pollastro, R.M., Hill, R.J., Jarvie, D.M., and Adams, C.W., 2004a, Geologic and organic geochemical framework of the Barnett-Paleozoic Total Petroleum System, Bend arch-Fort Worth basin, Texas, A merican A ssociation of Petroleum Geologists Annual Meeting Program Abstracts: American Association of Petroleum Geologists v. 13, p. A113.

Pollastro, R.M., Jarvie, D.M., Hill, R.J. and Adams, C.W., 2007, Geologic framework of the Mississippian Barnett Shale, Barnett-Paleozoic total petroleum system, Bend arch-Fort Worth B asin, Texas: A merican A ssociation of Petroleum Geologists Bulletin, v. 91; no. 4; p. 405-436. Accessed on May 12, 2010 at http://aapgbull.geoscienceworld.org/cgi/ content/full/91/4/405.

Railroad Commission of Texas, 2009a, The application of Petrohawk Operating Company to adopt temporary field rules for the Hawkville (Eagleford Shale) field, LaSalle County, Texas: Railroad Commission of Texas, Oil and gas docket no. 01-0263175. Accessed on May 12, 2010 at http://www.rrc.state.tx.us/meetings/ogpfd/ ogpofldrules/01-63175-frl.pdf.

Railroad Commission of Texas, 2009b, Newark, East (Barnett Shale) Field discovery date 10-15-1981: Railroad Commission of Texas, Data and Statistics. A ccessed on May 12, 2010 at http://www.rrc.state.tx.us/data/fielddata/ barnettshale.pdf.

Railroad Commission of Texas, 2010a, Eagle Ford Shale play: Railroad Commission of Texas. Accessed on May 12, 2010 at http://www.rrc.state.tx.us/eagleford/index.php.

Railroad Commission of Texas, 2010b, Haynesville/Bossier shale information: railroad Commission of Texas. A ccessed on May 12, 2010 at http://www.rrc.state.tx.us/bossierplay/ index.php.

Ratchford, M.E., Bridges, L.C., Jordan, D., Dow, W.G., Colbert, A., and Jarvie, D.M ., 2006, Organic geochemistry and thermal maturation analysis within the Fayetteville Shale study area - Eastern A rkoma basin and M ississippi Embayment regions, Arkansas: Arkansas Geological Survey Information Circular IC-37, 23 map pls. A ccessed on May 12, 2010 at http://www.geology.ar.gov/info_circulars/ ic37.htm. 
Repetski, J.E., Ryder, R.T., Weary, D.J., Harris, A.G., and Trippi, M .H., 2008, Thermal maturity patterns (CAI and $\% \mathrm{R}_{0}$ ) in U pper Ordovician and Devonian rocks of the A ppalachian basin-A major revision of USGS Map I-917-E using new subsurface collections: U.S. Geological Survey Scientific Investigations Map 3006. Available at http://pubs.usgs.gov/sim/3006/.

Rheams, K.F., and Neathery, T.L., 1988, Characterization and geochemistry of Devonian oil shale, north A labama, northwest Georgia, and south-central Tennessee (a resource evaluation): Alabama Geological Survey Bulletin 128, $214 \mathrm{p}$.

Rhoads, D.C., and Morse, J.W., 1971, Evolutionary and ecologic significance of oxygen-deficient marine basins: Lethaia, v.4, p. 413-428.

Ridgley, J.L., Hester, T.C., Condon, S.M., Anna, L.O., Rowan, E.L., Cook, T., and Lillis, P.G., 1999, Re-evaluation of the shallow biogenic gas accumulation, Northern Great Plains, USA - Is the similar gas accumulation in Southeastern A lberta and Southwestern Saskatchewan a good analog?, in Summary of Investigations 1999, v. 1: Saskatchewan Geological Survey, Saskatchewan Energy M ines, M iscellaneous Report 99-4.1.

Roen, J.B., 1993, Introductory review-Devonian and Mississippian black shale, eastern N orth A merica, in Roen, J.B., and Kepferle, R.C., eds., Petroleum Geology of the Devonian and M ississippian black shale of eastern N orth America: U.S. Geological Survey Bulletin 1909, p. A1-A8. Available at http://pubs.usgs.gov/bul/1909/report.pdf.

Roen, J.B., and Walker, B.J., eds., 1996, The atlas of major A ppalachian gas plays: The A ppalachian Oil and $\mathrm{N}$ atural Gas Research Consortium.

Rupp, J.A., 2008, Oil and gas in Indiana-A brief overview of the history of the petroleum industry in Indiana: Indiana Geological Survey. Accessed on May 12, 2010 at http://igs.indiana.edu/0 ilGas/.

Ryder, R.T., 1996, Cincinnati Arch Province (066), in Gautier, D. L., Dolton, G.L., Takahashi, K.I., and Varnes, K.L., eds., National assessment of U nited States oil and gas resources-Results, methodology, and supporting data: U.S. Geological Survey Digital Data Series 30, release 2. Accessed on May 12, 2010 at http://certmapper.cr.usgs.gov/ data/noga95/prov66/text/prov66.pdf.

Ryder, R.T., Swezey, C.S., Crangle, R.D., Jr., and Trippi, M.H., 2008, Geologic cross section $E-E^{\prime}$ through the A ppalachian basin from the Findlay arch, Wood County, Ohio, to the Valley and Ridge province, Pendleton County, West Virginia: U.S. Geological Survey Scientific Investigations Map 2985, 2 sheets, 48 p. pamphlet. Available at http://pubs.usgs.gov/sim/2985/.

Schad, S.T., 2004, Hydrocarbon potential of the Caney Shale in southeastern O klahoma: Tulsa, Okla., U niversity of Tulsa, Master's Thesis, $576 \mathrm{p}$.
Schmoker, J.W., 1993, Use of formation density logs to determine organic carbon content in Devonian shales of the western A ppalachian basin and an additional example based on the Bakken Formation of the Williston basin, in Roen, J.B., and Kepferle, R.C., eds., Petroleum geology of the Devonian and M ississippian black shale of eastern North America: U.S. Geological Survey Bulletin 1909B, p. J1-J14.

Schumaker, R.C., 1980, Porous fracture facies in Devonian shales of eastern K entucky and West Virginia: U.S. Department of Energy DOE/METC/SP-80/23, p. 124-132.

Smith, C.E., 2010, Kinder Morgan announces westbound Marcellus NGL pipeline: Oil \& Gas Journal, April 21, 2010 issue.

Stevens, Scott, Godec, Michael, and Moodhe, Keith, 2009, Gas Shale - Conclusion - New plays emerge, although environmental issues arise: Oil and Gas Journal, v. 107, issue 40.

Steward, Dan, Curtis, Brad, Givens, Natalie, and Steinsberger, Nick, 2006, Current state of Barnett Shale technology, A nnual M eeting Program: A merican A ssociation of Petroleum Geologists, v. 15, p. 101.

Streib, D.L., 1981, Distribution of gas, organic carbon and vitrinite reflectance in the eastern Devonian gas shales and their relationship to the geologic framework: U.S. D epartment of Energy, M organtown Energy Technology Center Report DOE/MC/08216-1276 (DE83007234), 262 p.

Stucker, J.D., Rowe, Harry, Rimmer, Susan, Ruppel, Stephen, and Loucks, Robert, 2008, Geochemical constraints on the depositional environment of the Barnett Formation, Permian Basin, West Texas, USA, 2008 Joint Meeting of The Geological Society of A merica, Soil Science Society of A merica, A merican Society of A gronomy, Crop Science Society of America, Gulf Coast Association of Geological Societies with the Gulf Coast Section of Society for Sedimentary Geology Paper no. 284-11: Geological Society of America. Accessed on May 12, 2010 at http://gsa.confex.com/gsa/2008AM/ finalprogram/abstract_151672.htm.

Sweeney, Joe, 1986, Oil and gas report and maps of Wirt, Roane, and Calhoun counties, West Virginia: West Virginia Geological and Economic Survey, Bulletin B-40, 102 p.

Swezey, C.S., 2002, Regional stratigraphy and petroleum systems of the Appalachian basin, North America: U.S. Geological Survey Geologic Investigations Series Map I-2768, 1 sheet. Available at http://pubs.usgs.gov/imap/i-2768/.

Swezey, C.S., 2008, Regional stratigraphy and petroleum systems of the Michigan basin, North America: U.S. Geological Survey Scientific Investigations Map 2978, 1 sheet. A vailable at http://pubs.usgs.gov/sim/2978/.

Swezey, C.S., 2009, Regional stratigraphy and petroleum systems of the Illinois basin, U.S.A.: U.S. Geological Survey Scientific Investigations Map 3068, 1 sheet. Available at http://pubs.usgs.gov/sim/3068/. 
True, W.R., 2010, CenterPoint to expand gathering, treating in Haynesville: Oil \& Gas Journal, v. 108, issue 16, May 3, 2010.

U.S. Department of Energy, National Energy Technology L aboratory (NETL), 2009, M odern shale gas development in the U nited States-A primer: U.S. Department of Energy, Office of Fossil Energy, National Energy Technology Laboratory. Accessed on June 26, 2012 at http://fossil.energy.gov/programs/oilgas/publications/ naturalgas_general/Shale_Gas_Primer_2009.pdf.

U.S. Department of the Interior (D OI), 2008, The N ational A tlas of the U nited States of A merica, A ccessed in 2008 at http://www.nationalatlas.gov/.

U.S. Environmental Protection Agency (EPA), 2011, Natural Gas Extraction-Hydraulic fracturing: United States Environmental Protection A gency. A ccessed on July 28, 2011 at http://water.epa.gov/type/groundwater/uic/class2/ hydraulicfracturing/index.cfm.

U.S. Geological Survey Marcellus Shale Assessment Team, 2011, Information relevant to the U.S. Geological Survey assessment of the $\mathrm{M}$ iddle Devonian $\mathrm{M}$ arcellus Shale of the Appalachian Basin Province, 2011: U.S. Geological Survey Open-File Report 2011-1298, 22 p. Available at http://pubs.usgs.gov/of/2011/1298/.

Walter L.M., M clntosh, J.C., B udai, J.M ., and M artini, A.M ., 2000, Hydrogeochemical controls on gas occurrence and production in the New Albany Shale: GasTIPS, v. 6, no. 2, p. 14-20.

Weaver, K eane, 2008, Drilling and completion in the shales of A ppalachia: Petroleum Technology Transfer Council Regional Seminar, May 29, 2008, Cambridge, Ohio.
West Virginia Geological and Economic Survey, 2010, Marcellus Wells 01012010 shapefile: West Virginia Geological and Economic Survey. Accessed on May 12, 2010 at http://www.wvgs.wvnet.edu/www/datastat/devshales.htm.

White, W.A., 1992, Displacement of salt by the Laurentide ice sheet: Quaternary Research, v. 38, p. 305-315.

Wilson, R.A., 1922, Oil in South Dakota: South Dakota Geological and Natural History Survey Bulletin 10, 97 p.

Wrightstone, Gregory, 2009, Marcellus Shale-Geologic controls on production, adapted from extended abstract prepared for oral presentation at A merican A ssociation of Petroleum Geologists Annual Convention, Denver, Colo., June 7-10, 2009: American Association of Petroleum Geologists Search and Discovery Article \#10206, Accessed on May 12, 2010 at http://www.searchanddiscovery.net/ documents/2009/10206wrightstone/images/wrightstone.pdf

Young, D.M., 1957, Deep drilling through Cumberland overthrust block in southwestern Virginia: A merican Association of Petroleum Geologists Bulletin, v. 41, no. 11, p. 2567-2573.

Zeilinski, R.E., and McIver, R.D., 1982, Oil and gas potential in Devonian gas shales of the A ppalachian basin: U.S. Department of Energy Report MLM-MU-82-61-0002 DOE/ DP/0053-1125 (Contract no. DE-AC04-76-DP00053), 326 p.

Zuber, M.D., Frantz, J.H., and Williamson, J.R., 1999, Reservoir evaluation of the Shrewsbury field, Edmonson County, Kentucky: GRI New Albany Shale Consortium Reservoir Characterization Report, p 64.
Publishing support provided by:

Denver Publishing Service Center, Denver, Colorado

For more information concerning this publication, contact: Center Director, USGS Central Energy Resources Science Center Box 25046, Mail Stop 939

Denver, CO 80225

(303) 236-1647

Or visit the Central Energy Resources Science Center Web site at: http://energy.usgs.gov/

This report is available at: http://pubs.usgs.gov/dds/dds-069/dds-069-z/ 

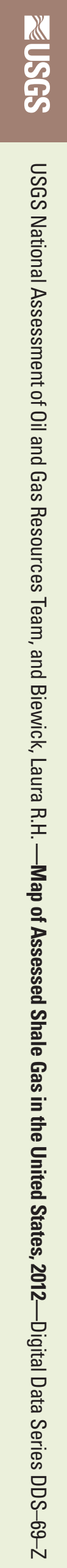